\title{
RANCANGAN SISTEM PENGADAAN STOK BARANG PADA PT. LAJU KARUNIA JAYA
}

\author{
Erna Astriyani ${ }^{1}$ \\ Rahmadi $^{2}$ \\ Ahmad Ricky Alfariz ${ }^{3}$ \\ Dosen STMIK Raharja Tangerang ${ }^{1}$, Mahasiswa STMIK Raharja Tangerang ${ }^{2,3}$ \\ J1 Jenderal Sudirman no.40, Modern, Cikokol Tangerang ${ }^{1,2,3}$ \\ Email : erna.astriyani@ raharja.info ${ }^{1}$,rahmadi@ raharja.info², ahmad.ricky@ raharja.info ${ }^{3}$
}

\begin{abstract}
ABSTRAK
PT. Laju Karunia Jaya merupakan perusahaan yang bergerak dibidang jasa kontruksi instalasi bangunan dan jalan raya, Sebagai sebuah perusahaan jasa tentunya menuntut operasional kerja yang sesuai dengan prosedur penyelesaian sebuah proyek pekerjaan. Bagian pengadaan barang berperan sangat penting dalam menunjang terlaksananya pekerjaan proyek, Terdapat kekurangan dan kendala pada sistem yang berjalan yaitu penerapannya masih menggunakan semi komputerisasi dan manual dimana barang yang masuk digudang diinput dari nota pembelian kedalam Microsoft excel serta barang yang akan keluar dari gudang masih menerapkan pencatatan manual dengan memo pada kertas, Hal ini menyebabkan lemahnya pengontrolan stok barang yang ada digudang yang berdampak kepada kekurangan stok barang maupun kelebihan stok barang serta sering terjadi ketidaksesuaian pelaporan barang, Dimana menyulitkan dalam proses mengadakan barang kembali pada gudang. Dari hasil analisa yang berjalan peneliti menggunakan metode pengumpulan data dan penggambaran dituangkan menggunakan Unified Modeling Language (UML). Hasil dari analisa ini dimaksudkan untuk mengembangkan sistem pengadaan stok barang berbasis website, yang mana pemanfaatannya sebagai pengontrolan data barang masuk dan barang keluar pada bagian gudang.
\end{abstract}

Kata kunci : Sistem, Pengadaan, Barang.

\section{ABSTRACT}

PT. The rate of gift Jaya is a company engaged in construction services and highway construction installation, As a service company certainly requires working in accordance with the operational procedures for settling an employment project. Part procurement very important role in supporting the implementation of the project work, are the shortcomings and constraints on systems running that application is still using semi computerized and manual where the goods into warehouse inputted from purchase orders into Microsoft Excel and the items will be out of the barn still applying registration manual with scrap paper, this led to weak control of the stocks held in warehouse which affect the shortages of goods and excess inventory, and often there is a discrepancy reporting items, Where complicate the process of procuring goods back to the warehouse. From the analysis that goes researchers used data collection methods and depiction poured using the Unified Modeling Language $(U M L)$. The results of this analysis are intended to develop a procurement system inventory based websites, which use as a data control goods in and goods out in the warehouse.

Keywords: Systems, Procurement of Goods. 


\section{PENDAHULUAN}

Perkembangan ilmu sistem informasi pada saat ini sangatlah pesat. Semakin dibutuhkannya sistem yang cepat untuk mengolah suatu informasi, setiap instansi ataupun perusahaan saling berkompetensi melakukan peningkatan sistem informasi yang lebih baik, antara lain mengembangkan sistem yang lebih kompleks dengan memanfaatkan teknologi yang ada pada saat ini.

Peranan sistem informasi pada instansi maupun perusahaan diterapkan pada berbagai bidang. Terutama pada suatu perusahaan mulai dari aspek manajemen, aspek keuangan, hingga aspek kepegawaian. Dalam setiap perusahaan akan selalu mencoba menerapkan sistem informasi yang efektif dan efisien untuk mencapai tujuan perusahaan. Segala aspek yang mengacu pada sistem informasi harus direncanakan, dilaksanakan dan dikendalikan dengan baik sehingga perusahaan mampu memanfaatkan sumber daya yang ada. salah satu contohnya pada pemanfaatan persediaan barang. Persediaan barang dianggap sebagai salah satu modal suatu perusahaan. Sehingga perusahaan perlu melakukan manajemen yang berkesinambungan dengan kata lain perusahaan harus mampu mengantisipasi keadaan yang ada dalam manajemen persediaan untuk mencapai tujuan dalam manajemen perusahaan dan untuk meminimalisir pengeluaran yang harus dikeluarkan oleh perusahaan dalam penanganan persediaan barang.

Dalam suatu perusahaan masih banyak yang belum menggunakan sistem informasi dengan efisien dan akurat bahkan masih ada yang belum terkomputerisasi dalam penyajian data sehingga dalam prosesnya banyak memakan waktu dan rentan terhadap keakuratan dalam penyajiannya terutama peranan dalam manajemen penyediaan barang.

\section{RUMUSAN MASALAH}

Sistem pengadaan stok barang pada PT. Laju Karunia Jaya yang berjalan saat ini masih menerapkan sistem manual dan semi komputerisasi yaitu pada bagian staff gudang masih menginput barang masuk dari nota pembelian barang kedalam Microsoft excel, kemudian untuk barang keluar masih ditulis dengan manual yaitu hanya berupa sebuah memo yang ditulis dikertas dan untuk pelaporan dan pengarsipan diinput kembali kedalam Microsoft word.

\section{LITERATUR RIVIEW}

1. Penelitian yang dilakukan oleh Sri Rahayu, Tuti Nurhaeni dan Malidah Rohmah pada tahun 2014 yang berjudul "Sistem Persediaan Alat Tulis Kantor Sebagai Penunjang Pengambilan Keputusan Bagian Logistik Di Perguruan Tinggi Raharja". dengan adanya penelitian ini dapat disimpulkan bahwa, Transaksi yang terjadi setiap harinya secara otomatis digeneralisasi ke laporan dengan cepat dan akurat sedangkan perihal laporan stock barang ini menjadikan kemudahan untuk mengambil keputusan barang-barang ATK apa saja yang akan dibeli untuk persediaan bulan berikutnya serta dalam memenuhi permintaan barang setiap divisi perguruan tinggi dapat direalisasikan karena stok barang tersedia.

2. Penelitian yang dilakukan oleh Fery Maulana pada tahun 2015 yang berjudul "Sistem Penunjang Keputusan Pengadaan Material Listrik Pada PT. PLN Teluknaga Berbasis Web. dengan adanya penelitian ini disebabkan karena banyaknya permasalahan gangguan listrik dilapangan, membuat material harus selalu tersedia, sedangkan banyak kekurangan stok material disaat petugas lapangan meminta material yang dibutuhkan. dengan dibuatnya sistem ini, diharapkan kebutuhan pengadaan material listrik terpenuhi dan dapat menunjang keputusan dalam pengadaan material listrik kedepannya. 
3. Penelitian yang dilakukan oleh Rahmat Hidayat "Penerapan e-Procurement Dalam Proses Pengadaan Barang Dan Jasa Pemerintah Guna Mendukung Ketahanan Tata Pemerintahan Daerah (Studi Pada Unit Layanan Pengadaan Barang Dan Jasa Pemerintah Kabupaten Penajam Paser Utara Provinsi Kalimantan Timur)". Penelitian ini untuk menganalisis penerapan prinsip e-procurement pada Unit Layanan Pengadaan Barang dan Jasa di Pemerintah Kabupaten Penajam Paser Utara. Mendukung Proses Monitoring dan Audit. Hal ini ditandai bahwa semua data mengenai pengadaan barang dan jasa atau biasa disebut lelang, akan tersimpan terus dalam Sistem Pengadaan Barang dan Jasa (SPSE) dan website, sehingga memudahkan KPK, BPK, Lembaga Kebijakan Pengadaan Barang. Memenuhi Kebutuhan Akses Informasi secara Real Time.

4. Penelitian yang dilakukan oleh Andy Wijaya, Muhammad Arifin dan Tony Soebijono pada tahun 2013 yang berjudul "Sistem Informasi Perencanaan Persediaan Barang". pada implementasi penelitian ini dapat disimpulkan aplikasi ini dapat memberikan solusi untuk menentukan jumlah pemesanan barang yang optimal dan ekonomis, menentukan kapan harus melakukan pemesanan barang, serta dengan metode Economic Order Quantity dapat mengoptimalkan pengadaan barang persediaan serta dapat meminimalkan biaya persediaan.

5. Penelitian yang dilakukan oleh Suprayitno dan Uli Indah Wardati pada tahun 2012 yang berjudul "Pembangunan Sistem Stok Barang Dan Penjualan Pada Toko Sero Elektronik". dalam penelitian ini sistem yang berjalan masih secara konvensional dalam pendokumentasian data seperti data barang yang masuk dan data penjualan masih dicatat dalam buku untuk mengelola stok barang dan penjualan. Dengan adanya sistem ini diharapkan dapat membantu proses pembuatan laporan penjualan bulanan serta memudahkan penyampaian informasi pada pegawai lain dengan fitur-fitur yang ada di dalamnya.

6. Penelitian yang dilakukan oleh Siti Fatimah pada tahun 2014 yang berjudul "Rancangan Sistem Informasi Pengadaan Barang Habis Pakai Pada PT. Bangun Nagamas Kontraktor". Dalam penelitian ini sistem yang berjalan belum tersedianya sistem persediaan barang sehingga belum bisa mengontrol stok barang yang tersedia. Oleh karena itu, pada skripsi ini akan dibangun sistem informasi suatu sistem pengadaan barang yang berbasis web, sehingga informasi tentang stok barang dapat diketahui secara jelas dan terperinci.

7. Penelitian yang dilakukan oleh Khanna Tiara, Dewi Immaniar dan Fiqih Arzia pada tahun 2015 yang berjudul "Penerapan Sistem Inventory Laboratorium Digital Dengan Metode Critical Succes Factor pada Perguruan Tinggi Raharja". dalam penelitian ini sistem yang berjalan masih dilakukan secara manual terutama dalam pencatatan terhadap inventory peralatan yang ada di Lab. SK, dangan adanya sistem yang diusulkan diharapkan dapat memudahkan Perguruan Tinggi Raharja untuk memonitoring pengumpulan data barang, memonitoring peminjaman barang dan pembuatan laporan didalam lab.

\section{PEMECAHAN MASALAH}

1. Membuat suatu sistem informasi pengadaan barang yang terkomputerisasi secara kesuluruhan sehingga keadaan stok barang dapat disajikan datanya secara cepat dan akurat.

2. Membuat suatu sistem informasi pengadaan barang yang dapat disajikan secara update dari keadaan barang yang ada digudang kepada engineering manager dan administration manager sehingga barang yang dibutuhkan dalam pengerjaan proyek dapat terpenuhi dan berdampak baik kepada ketepatan penyelesaian proyek 
3. Mengembangkan suatu manajemen pengadaan barang yang akurat dengan keadaan operasional proyek sehingga barang yang ada pada gudang dapat diterpakai sesuai dengan kebutuhan pengerjaan proyek dan administration manager tidak mengalami kesulitan dalam memenuhi stok barang serta menghindari kelebihan stok barang (overstock) yang ada pada gudang.

\section{IMPLEMENTASI}

Prosedur sistem pengadaan barang yang sedang berjalan pada PT. Laju Karunia Jaya sebagai berikut :

1. Engineering Manager melakukan permintaan barang yang dibutuhkan pada saat operasional pengerjaan proyek kepada Staff Gudang.

2. Staff Gudang menerima surat permintaan barang dari Engineering Manager kemudian memeriksa stok barang yang tersedia di Gudang.

3. ketika permintaan barang dari Engineering Manager tersedia maka staff gudang mengirim barang dan membuat laporan barang keluar kepada Administration Manager.

4. Engineering Manager menerima barang dan membuat laporan penerimaan barang kepada Administration Manager.

5. Administration Manager menerima laporan penerimaan barang dari Engineering Manager dan laporan pengeluaran barang dari staff gudang kemudian melakukan pengkajian untuk melakukan pengadaan barang pada gudang.

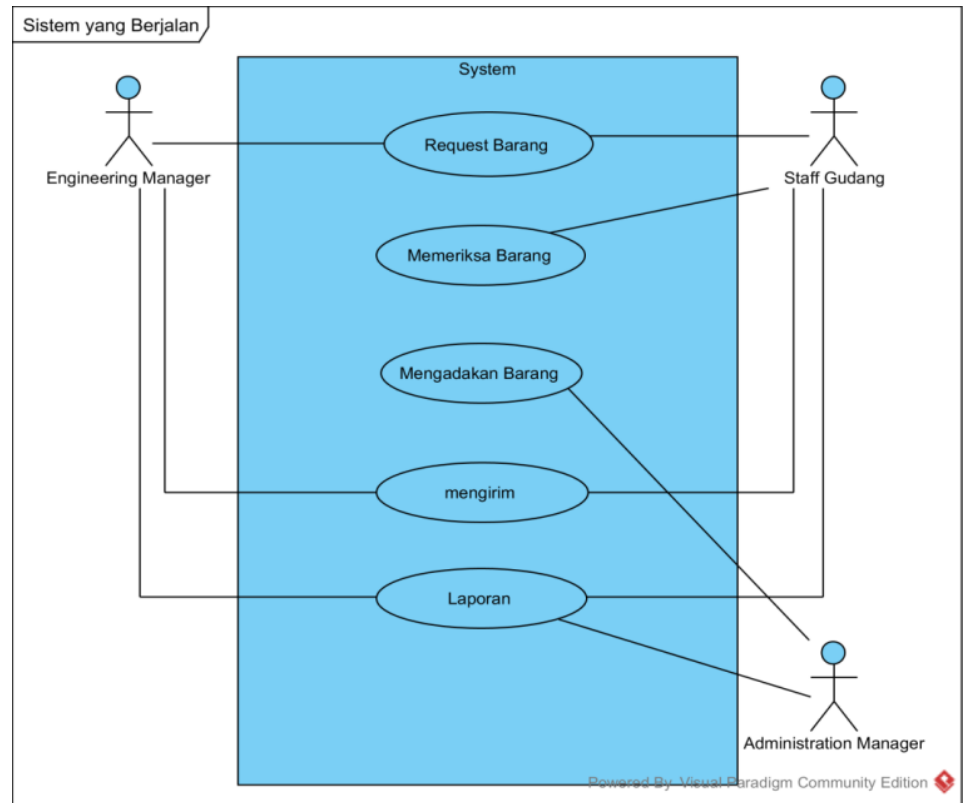

Gambar 1. Rancangan Use Case Prosedur Sistem yang Berjalan

Gambar Use Case Diagram Pengadaan Barang

Berdasarkan gambar Use Case Diagram yang berjalan saat ini terdapat :

a. 1 (Satu) Sistem Pengadaan Barang.

b. 3 (Tiga) Actor yang melakukan kegiatan diantaranya : Engineering Manager, Staff Gudang dan Administration Manager

c. 5 (Lima) Use Case yang diakukan oleh actor-actor tersebut diantaranya : request barang oleh engineering Manager kepada staff gudang, memeriksa barang yang direquest dari engineering manager dilakukan oleh staff gudang, mengadakan barang oleh administration manager setelah menerima dan mengkaji laporan barang keluar dari staff gudang dan laporan barang diterima dari engineering Manager, mengirim dilakukan oleh staff gudang kepada engineering manager, Laporan yaitu diantaranya staff gudang membuat laporan barang keluar dan engineering manager membuat laporan penerimaan 
barang kemudian laporan tersebut disajikan kepada administration manager untuk dikaji kembali guna memenuhi permintaan barang yang dibutuhkan oleh engineering manager dan ketersediaan barang yang ada pada gudang.

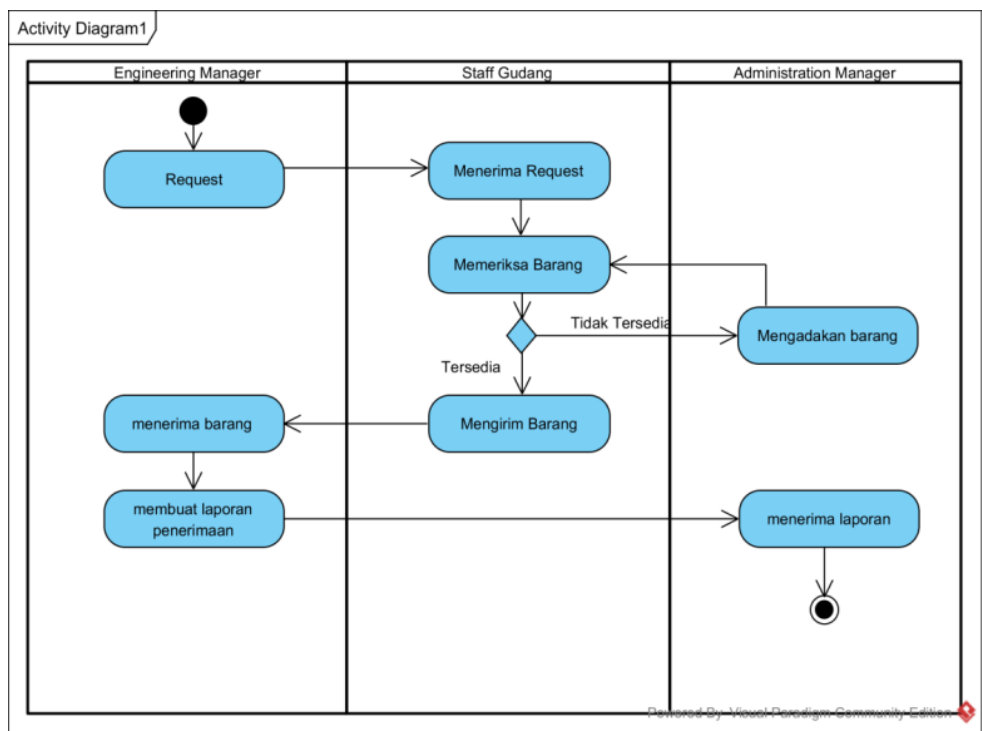

Gambar 2. Activity Diagram Pengadaan Barang

Berdasarkan gambar Activity Diagram saat ini terdapat :

a. 1 (Satu) Initial Node, Obyek yang diawali.

b. 8 (Delapan) Action State dari sistem yang mencerminkan eksekusi dari suatu aksi.

c. 1 (Satu) Decision Node yang mencerminkan sebagai pilihan eksekusi.

d. 1 (Satu) Final State, Obyek yang diakhiri

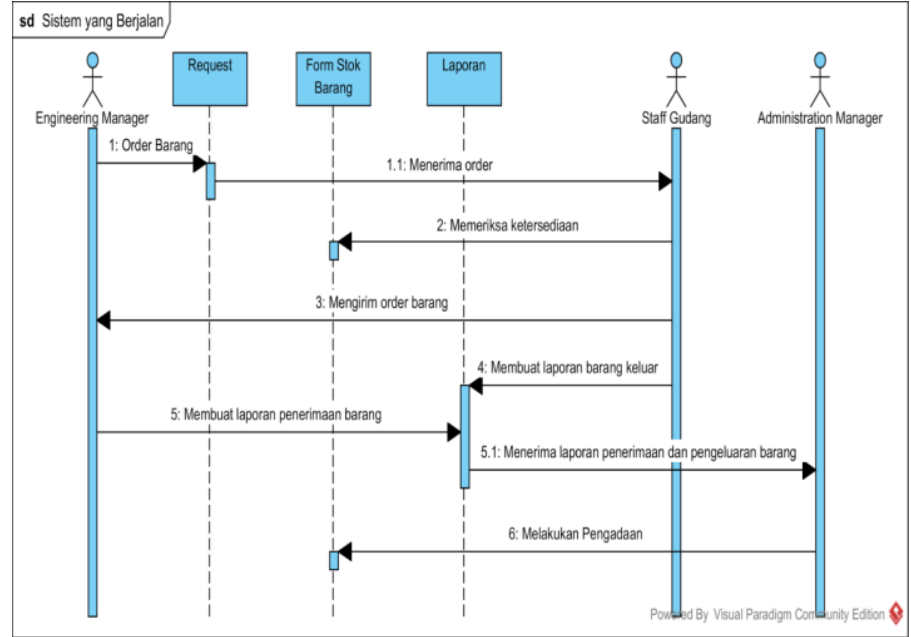

Gambar 3. Sequence Diagram Pengadaan Barang

Berdasarkan gambar Sequence Diagram yang berjalan saat ini terdapat :

a. 3 (Tiga) Actor yang melakukan kegiatan diantaranya : Engineering Manager, Staff Gudang dan Administration Manager.

b. 7 (Tujuh) Massage Spesifikasi dari komunikasi antar objek yang memuat informasiinformasi mengenai aktifitas yang terjadi.

\section{KESIMPULAN}

1. Kendala yang sering terjadi pada sistem pengadaan stok barang pada PT. Laju Karunia Jaya yang berjalan saat ini yaitu ketika ada permintaan barang dari bagian operasional, 
staff bagian gudang masih kesulitan mengetahui keadaan stok barang, sedangkan dari segi pelaporan barang sering terjadi ketidaksesuaian data barang yang ada pada komputer dangan keadaan barang yang tersedia pada gudang serta kurang terkontrolnya barang yang ada pada gudang berdampak pada bagian administrasi dalam mengadakan barang mana yang harus disediakan kembali digudang.

2. Dari kendala yang sering terjadi pada sistem pengadaan stok barang yang ada pada PT. Laju Karunia Jaya, maka peneliti lebih mereferensikan kepada pengendalian dan pengontrolan barang secara cepat dan akurat sehingga dalam pengelolaan pengadaan stok barang yang ada pada gudang dapat dilakukan secara efisien namun tetap terjaga keakuratan datanya.

\section{DAFTAR PUSTAKA}

[1] Darmawan, Deni. Nur Fauzi, Kunkun. 2013. "Sistem Informasi Manajemen". Bandung : PT Remaja Rosdakarya.

[2] Fatimah, Siti. 2014. "Rancangan Sistem Informasi Pengadaan Barang Habis Pakai Pada PT. Bangun Nagamas Kontraktor".

[3] Ginting, ElizaAndyani.2013. "Aplikasi Berbasis Web E-Commerge Menggunakan Joomla pada Mutiara Fashion. Universitas Widyatama".

[4] Jogiyanto Bukunya Yakub. 2012. "Pengantar Sistem Informasi”. Graha Ilmu.

[5] Jogiyanto, Hartono. 2010. "Analisis dan Desain Sistem Informasi”, Edisi III. Yogyakarta: ANDI.

[6] Kadir, Abdul. 2014. "Pengenalan Sistem Informasi”. Yogyakarta : Andi.

[7] Maimunah, Lusyani Sunarya, dan Nina Larasati. 2012. "Media Company Profile Sebagai Penunjang Informasi dan Promosi”. Jurnal CCIT Vol-5 No.3. (Mei 2012).

[8] Mardi. 2011. "Sistem Informasi Akuntansi.” Bogor : Ghalia Indonesia.

[9] Maulana Fery. 2015. "Sistem Penunjang Keputusan Pengadaan Material Listrik Pada PT. PLN Teluknaga Berbasis Web. 